\title{
New models related with heating and cooling of an old building in Évora (South of Portugal)
}

\author{
M.R. Duque ${ }^{1}$ \\ ${ }^{1}$ Department of Physics, School of Sciences and Technologies \\ Évora University \\ Rua Romão Ramalho 59, 7000-671 Évora (Portugal) \\ Phone number:+00351266745372,fax: 351266 745394, e-mail: $\underline{\operatorname{mrad} @ \text { uevora.pt }}$
}

\begin{abstract}
The work presented here is part of a more extensive study related to a system of heating and cooling an old building of the 16th century, of the Evora University using water retired from four boreholes located in the vicinity of the building. The principal aim of this work is to introduce solar radiation data including its variations during a day, in winter and in summer and use them as a limit to the direct solar radiation received by the building, Our models include heat transfer by conduction, convection and radiation. A special attention is dedicated to temperature and humidity values needed to work. The results obtained are used to program the time interval and the conditions of operation of the system mounted in the building.
\end{abstract}

\section{Key words}

Old building, heating, cooling, solar radiation, heat pumps

\section{Introduction}

With the increasing price of the electricity and the problem of atmospheric pollution, an effort was made to inform people about the needs of changing the way of cooling and heating the buildings. In our days, we have comfortable buildings using direct solar energy. The study of the energy needs of new buildings is now obligatory. Models about the needs for heat or cool a new building can be found on the literature, and people can choose the method of doing that, including the type of energy used. The situation is completely different for old buildings. The main objectives of our work is to make heating and cooling models for an old building, the College of the Holy Spirit, from the Évora University, using water connected in boreholes located in the vicinity of the building. This work is an extension of another one [1] presented during 2014.

In order to obtain the energetic needs to have good conditions for work and study (the building has classrooms and administrative offices), we will consider gains and losses of energy, obtained by conduction, convection and radiation. Special attention is given to the effect of direct sunlight in external walls and roof of the building, using, for this purpose, hourly values of solar radiation, measured in the Évora Observatory. In previous works, an average value of solar radiation incident on the building was used.

\section{Main characteristics of the building}

The College of the Holy Spirit was built in the sixteenth century, and has cloisters and walls partially covered with tiles of the seventeenth century. The building was constructed for a university and has many classrooms and rooms for administration offices. Its a building with thick walls and covered with clay tiles. Our study is related with the rooms located in the cloisters, on the ground floor of the building. All of them have one door (made of wood) and two windows, located in the same wall. We made the study for one room, and considered all the rooms with the same dimensions. A separate study was made for rooms located on the left and right wing of the cloisters. The room measured has dimensions of $6,72 \mathrm{~m} \mathrm{x}$ $10.19 \mathrm{~m} \times 4.25 \mathrm{~m}$. The thickness of the walls is $0.705 \mathrm{~m}$. The door is made from dark wood, has dimensions of $2.42 \mathrm{~m} \times 1.46 \mathrm{~m}$ and its minimum thickness is $0.05 \mathrm{~m}$. The windows have dimensions of $1.33 \mathrm{~m} \times 1.12 \mathrm{~m}$. They can be protected by dark wood doors, with a thickness of $0.05 \mathrm{~m}$. The tiles of the walls, outside and inside the rooms, are blue and white, and the parts without tiles are white walls. The walls opposite to the windows are leaning on rock gneiss. The floor and the ceiling of the rooms are covered with wood. The interior walls (2) communicate with other identical rooms. They do not enter in our calculations.

\section{The climate of Évora}

The climate of Évora is typically Mediterranean, with some Atlantic influence. Temperatures registered during Spring and Autumn are close to the desired temperatures for learn and work with comfort. The average maximum temperature values range between $14^{\circ} \mathrm{C}$ in January and $33^{\circ} \mathrm{C}$ in July and august. The average minimum temperature values range between $5^{\circ} \mathrm{C}$ in January and $16^{\circ} \mathrm{C}$ in July and August. Sometimes, temperature values of $0^{\circ} \mathrm{C}$ or less are registered during the night, in Winter, and $40^{\circ} \mathrm{C}$ during several consecutive days, in Summer . For these reasons, we made models trying to estimate the heat necessary to heat the rooms in Winter and the heat we must extract from the rooms on Summer. 
Another important parameter is related with the number of hours of sunshine and the amount of clouds. On Fig 1 we can see the maximum and minimum average temperatures obtained in the different months of the year. We can also see a graph with the average hours of sunshine during a day.

1.
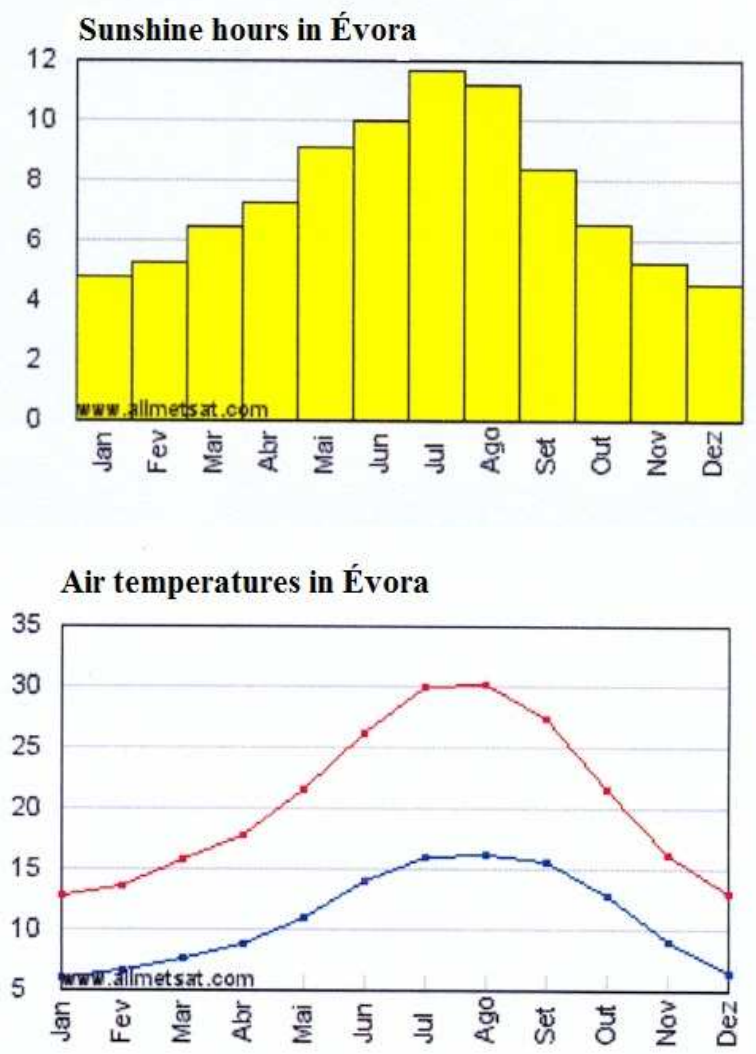

2.

Fig 1. Average values of sunshine hours obtained during the year. 2. Maximum and minimum average temperature values measured in Évora since January to December.

In this work, we also use values of direct solar radiation incident in the walls of the building. As we said, the building has a right and a left wing in the cloisters. This means that the sun beats down at different times in different parts of the building. On Fig 2 we can see the values of total solar energy measured in the Observatory of the University of Évora, in December $31^{\text {st }} 2013$. We can easily see that it not exist any symmetry between the values obtained during the day.

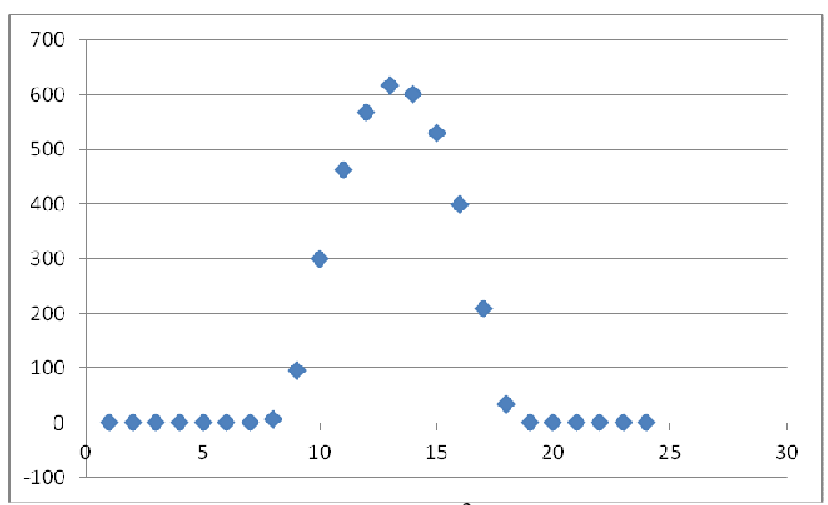

Fig 2. Direct solar energy $\left(\mathrm{mW} \mathrm{m}^{-2}\right)$ obtained at different hours of a day in January 2013, without clouds.
Looking to this graph we can see that positive values only occur between 8 and $18 \mathrm{pm}$. The maximum value $\left(616.49 \mathrm{~W} / \mathrm{m}^{2}\right)$ occurs at $13 \mathrm{pm}$.

\section{The water}

The water used to heat and to cool the building, is retired from four boreholes, each one with $100 \mathrm{~m}$ depth, located near the building. Temperature measurements were made in one hole (RA4) since January 2013 to September 2013. Temperature was measured at several depths using temperature probes. The temperature of the water, from 30 to $90 \mathrm{~m}$ depth, was $18^{\circ} \mathrm{C}$ in January and $19^{\circ} \mathrm{C}$ during almost the period of measurement. The water comes, from the holes to the building, inside polyethylene pipes with a thermal conductivity of 0,35 $\mathrm{W} /(\mathrm{K} \mathrm{m})$ and a wall thickness of $4.6 \mathrm{~mm}$. The pipes are buried under the ground at $0,70 \mathrm{~m}$ depth. An electrical dipole-dipole profile was undertaken, to verify the extent of the occurrence of water deposits in the soil and the existence of hydraulic connections between two holes in the region (RA4 and RA3) [2]Flow tests performed in the holes indicate flow rates between 6001/hour (hole RA4) and 10000 1/hour (hole RA1) [4]. Transmissivity values obtained in the holes are $0,30 \mathrm{~m}^{2} /$ day in hole RA4, 0.41 $\mathrm{m}^{2} /$ day in RA3, $0.80 \mathrm{~m}^{2} /$ day in RA2, and $2.64 \mathrm{~m}^{2} /$ day in RA1 [4].

\section{Models and data used}

We made calculations considering a day and a night with mean temperature values obtained in July and August, and a day and a night with mean temperature values obtained in January. In this work, we present only the values obtained for January. Heat transfer by conduction, convection and radiation was considered. The air outside the rooms was considered moving with a velocity of $1 \mathrm{~m} / \mathrm{s}$ and the coefficient of heat convection used was $q=9,045$ $\mathrm{v}$ [3]. The thermal conductivity of the walls was estimated as $\mathrm{K}=1.4 \mathrm{~W} /(\mathrm{K} \mathrm{m})$. For the wood of the doors and floor, a value of $0.140 \mathrm{~W} /(\mathrm{K} \mathrm{m})$ was used, and for the glass of the windows, the value used is $1.0 \mathrm{~W} /(\mathrm{K} \mathrm{m})$. The emissivity used for white walls is 0.9 , for the tiles is used 0.85 , for glass 0.84 and for dark wood 0.82 . An average absorption coefficient of solar radiation of 0.6 was used.

In order to obtain environmental conditions suitable for work in classrooms, we used a temperature of $22^{\circ} \mathrm{C}$ inside the room during the day and the need to obtain a suitable ventilation ( this means that the doors must be opened during some periods of the day- the minimum fresh air requirements in classrooms is $8 \mathrm{~L} / \mathrm{s}$, per student). The mean temperature value for the air outside the room is $11.8{ }^{\circ} \mathrm{C}$. The temperature used for the air in the space beneath the cloister arches, near de wall, during the day is $12.8^{\circ} \mathrm{C}$. For the temperatures of the air in a winter night, the values used are $7.2{ }^{\circ} \mathrm{C}$ and $8.2^{\circ} \mathrm{C}$ respectively. For the temperature of rock (gneiss) and soil we used values of $17^{\circ} \mathrm{C}$. Due to the cloister configuration only a small part of the front of the room receives direct solar radiation in a relatively small period of time, during the day. In one side of the cloister the sun strikes the wall 
during part of the morning and on another part the sun incidence occurs in the evening. This means that the amount of direct solar energy received is different in the right and left wings of the cloister.

\section{Results obtained for a winter night}

During the night, the doors and the protecting doors of the windows are closed. There is no transfer of air between the rooms and the air outside the building. Values of solar radiation measured between 19 and 7 hours pm were used. The results obtained are summarized in table I.

Table I - Results obtained for the night

\begin{tabular}{|l|c|}
\hline \multicolumn{1}{|c|}{ TYPES OF HEAT TRANSFER } & VALUES OBTAINED \\
\hline Conduction & $1178 \mathrm{~J} / \mathrm{S}$ \\
\hline Convection & $391.7 \mathrm{~J} / \mathrm{s}$ \\
\hline Radiation & $189.2 \mathrm{~J} / \mathrm{s}$ \\
\hline
\end{tabular}

The value obtained with Fourier law of conduction were calculated for the front wall, considering the effect of the door (made of wood with a different thickness) and windows ( a difference of $2^{\circ} \mathrm{C}$ was considered between the internal and the external face of the window). The conduction between the ground floor and the adjacent rock was discarded due to the similarity between the temperatures of the two media. The value obtained for convection is related only with heat removed by convection from the exterior wall. Air movement was not considered inside the room during the night. The values obtained by radiation were obtained using the Stefan Boltzman law. The values used for direct solar energy during the night have negative values (the surface of the Earth looses energy). Using all the data measured, the heat lost by the surface during the night, is $0.04 \mathrm{w} / \mathrm{m}^{-2}$. This means a total of $43,3 \mathrm{~J} / \mathrm{s}$ in a surface identical to the front wall. This value, compared with the value presented in the table, was discarded.

Comparing the values obtained, we can say that the heat lost by conduction is higher than the sum of the heat lost by convection outside the wall and the heat lost by radiation. This can be interpreted saying that the heat lost by conduction was overestimated The temperature used for the air inside the room is $22^{\circ} \mathrm{C}$ and this is the value used during the day. In the early morning, the temperature inside the room can be smaller. The velocity of the wind can be higher than the value considered and the heat lost by convection can be underestimated. Finally, the value used for the temperature of the wall was obtained from mean air temperatures registered in January in the city of Évora. We can say that we can have, in the cloisters, near the wall, heat transfer by diffusion.

\section{The wall- How it works}

Our calculations leads to a heat loss by conduction through the front wall of $1178 \mathrm{~J} / \mathrm{s}$. In an attempt to understand the implications of this lost in the temperature values inside the room we made a small model using the properties inserted in table II.
Table II- Some properties of the wall and air

\begin{tabular}{|l|c|}
\hline \multicolumn{1}{|c|}{ PROPERTIES } & VALUES \\
\hline Density of the walls & $1500 \mathrm{~kg} / \mathrm{m}^{3}$ \\
\hline Specific heat of the wall & $666 \mathrm{~J} /(\mathrm{kg} \mathrm{K})$ \\
\hline Density of the air & $1.196 \mathrm{~kg} / \mathrm{m}^{3}$ \\
\hline Specific heat of the air & $1007 \mathrm{~J} /(\mathrm{kg} \mathrm{K})$ \\
\hline
\end{tabular}

Neglecting the effect of the window and the door it is possible to obtain the mass of the front wall and the energy needed to alter its temperature by $1^{\circ} \mathrm{C}$. With this value and the value of the heat lost by conduction, we can conclude that it is necessary a time interval of 7,19 hours to make the alteration mentioned. This means that during the period of night considered the temperature of the wall decreases $1{ }^{\circ} \mathrm{C}$. In fact, due to the thermal inertia of the wall, we have this effect.

What can we say about temperature variations of the air inside the room, during the night? Making a calculation similar to that made for the wall, considering a volume of air of $291 \mathrm{~m}^{3}$, we can say that the heat necessary to make a change of $1^{\circ} \mathrm{C}$ in the air is $350,472 \mathrm{~J}$.

\section{Results obtained for a winter day}

The results obtained for the heat lost by conduction in a winter day, includes the heat transferred to the rock through the back wall $(430 \mathrm{~J} / \mathrm{s})$, the heat lost from the floor $(479.4 \mathrm{~J} / \mathrm{s})$ and the heat lost through the front wall $(961.9 \mathrm{~J} / \mathrm{s}$.$) .$

Table III - Results obtained for the day

\begin{tabular}{|l|c|}
\hline TYPES OF HEAT TRANSFER & VALUES OBTAINED \\
\hline Conduction & $1871,3 \mathrm{~J} / \mathrm{S}$ \\
\hline Convection & $483.4 \mathrm{~J} / \mathrm{s}$ \\
\hline Radiation & $244.4 \mathrm{~J} / \mathrm{s}$ \\
\hline
\end{tabular}

The result for heat convection was obtained considering that the protecting doors of the windows are open, and the windows and doors are closed. The values obtained for the heat lost by conduction is higher than the sum of the heat lost by convection or by radiation. The value obtained by conduction can be overestimated. The temperatures of the rock and the soil, near the back wall and over the floor, increases with the time of heating the building, the value of the thermal gradient is less than the value used.

The solar incident energy values, measured in Évora, during the day change between $6.46 \mathrm{~W} / \mathrm{m}^{2}(8 \mathrm{pm})$ and $616.49 \mathrm{~W} / \mathrm{m}^{2}$ (13pm).For the calculation of the energy received we must know the value of the coefficient of absorption, $\alpha$. We used values of $\alpha=0.26$ for the tiles and white wall, and $\alpha=0.59$ for the wood of the doors. A transmissivity value of 0.88 was used for the glass of the windows.

Due to the orientation of the cloisters, direct solar radiation reaches the front wall of the rooms only in the evening or in the early morning. We consider that only $50 \%$ of the wall is achieved, due to the cloister configuration. Calculations with direct solar energy are different in the two wings of the cloisters. In one side, the sun rays strikes the wall between 9-10 pm (the average 
value used for incident solar energy is $200 \mathrm{~W} / \mathrm{m}^{2}$ ). On the other wing of the cloisters the sun strikes the wall between 16-17 pm (the average value used for incident solar energy is $300 \mathrm{~W} / \mathrm{m}^{2}$ ). A correction of $50 \%$ was made, for the inclination of the solar rays with the ground. The values obtained for the energy absorbed by the door and wall, in the morning is $(87.9+478.4=575.3 \mathrm{~W})$. The values obtained for the period in the evening is $(92.2+717.6=809.8 \mathrm{~W})$. Values of $262 \mathrm{~W}$ and $393 \mathrm{~W}$ were obtained for the energy transmitted through the glass of the windows, in the morning and in the evening.

Considering a value of $291 \mathrm{~m}^{3}$ of air in the room and one hour of sun incidence, the change of the air temperature in the air, due to the heat transmitted through the windows, in the morning, is $2.7^{\circ} \mathrm{C}$, and in the evening $4^{\circ} \mathrm{C}$. This effect occurs only in days without clouds. In general the protecting doors of the windows are open, during the day, in order to have sunlight in the room.

Due to the high value of the mass of the wall, the heat absorbed in the morning and in the evening does not produce a detectable change in the temperature of the window.

When the door is open, the cool air enters and tends to head toward the back wall replacing the hot air that tends to rise, forming a convection cell.

\section{Our proposal}

The results obtained with our model shows that is no need of heating the building, during the night, when the temperatures are close to the values used. The energy lost during the night can be supplied by the walls of the building. The change in $1{ }^{\circ} \mathrm{C}$ in temperature of the wall can be replaced with the heating during the day.

The energetic needs to heat the rooms greatly depends on the periods of time with the door open.

We propose to heat the room with water collected from four holes located near the building. After running through the building, the water must return to the holes. In winter, the temperature inside the holes is $18^{\circ} \mathrm{C}$. We want to heat the air inside the room to a temperature of $25^{\circ} \mathrm{C}$. The water coming from the holes must pass through a compressor in order to increase to a temperature of $28^{\circ} \mathrm{C}$. Using a minimum power of $7 \mathrm{~kW}$ and a mass flow rate of $0.16 \mathrm{~kg} / \mathrm{s}$ it is possible to obtain the desired temperature. After that, the water goes to a heat exchanger where its temperature decreases to $18^{\circ} \mathrm{C}$ and the air temperature increases from $20^{\circ} \mathrm{C}$ to $25^{\circ} \mathrm{C}$. Using a water flow rate of $0.08 \mathrm{~kg} / \mathrm{s}$ per room, it is possible to heat $560 \mathrm{~L} / \mathrm{s}$ of air. We can think on classes with 20 to30 students. This means that in order to obtain a change in the air needed for comfort, we need 160 to $240 \mathrm{~L} / \mathrm{s}$. Speaking about temperatures, in order to obtain the energy needs presented in Table III, it would be necessary to inject about $518 \mathrm{~L} / \mathrm{s}$ of air at $25^{\circ} \mathrm{C}$, to obtain an air temperature of $22^{\circ} \mathrm{C}$, inside the room.

We did not consider the effect of humidity. In fact, January is the month of the year with more raining days and with elevated values of humidity. This fact can compromise seriously the thermal comfort in the room.

\section{Final considerations}

The principal difference between the models for this building and the new ones is the high values of thermal inertia of the walls. This fact is directly related with very small temperature changes, occurring during the night, when the doors are closed. The design and orientation of the cloisters makes a difference between the amount of direct solar energy received in the different wings. Only one half of the area of the wall receives directly energy from the sun. Temperatures and thermal gradient values, used for gneiss rock, were not measured. The study was done considering only rooms in the ground floor, with rooms in the first floor with no influence in our model. The solution of the problem of the heating in the winter is easy to solve. The next step is to make the same type of study for a summer day. In that case we must consider a cooling problem and the effect of direct solar radiation must be included in the calculus. This study was done using average temperature values and the results obtained must be seen as average results.

\section{Acknowledgement}

Direct solar radiation data were obtained in the Observatory of CGE. We want to thank to Samuel Bárias who treated and furnished the data.

\section{References}

[1] Duque, M.R., Pascoal, J., "Models for heating and for cooling an old building using water from boreholes", in Proc.,ICWWM,2014

[2] Duque,M. R., "A study made using geothermal energy to heat and cool an old building", Proceedings of the CIIEM, Lisbon, July 2013.

[3] Glassley, W. E., "Geothermal Energy and the Environment",CRC Press, Taylor\& Francis Group,2010.

[4] Montes, V. "Captação de Águas Subterrâneas para Aproveitamento Geotérmico-caso de Estudo do colégio do Espírito Santo”, Universidade de Évora (internal report), 2009. 